INSIGHTS INTO REGIONAL DEVELOPMENT

ISSN 2669-0195 (online) http://jssidoi.org/IRD/

2020 Volume 2 Number 4 (December)

http://doi.org/10.9770/IRD.2020.2.4(2)
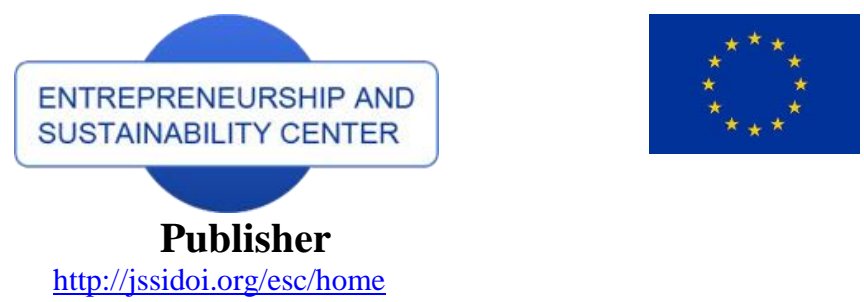

\title{
CLUSTERIZATION OF PUBLIC PERCEPTION OF NUCLEAR ENERGY IN RELATION TO CHANGING POLITICAL PRIORITIES
}

\author{
Dainius Genys ${ }^{1}$, Ričardas Krikštolaitis ${ }^{2}$ \\ ${ }^{1,2}$ Vytautas Magnus University, Donelaičio 58, Kaunas, Lithuania \\ E-mails: ${ }^{1}$ dainius.genys@vdu.lt ${ }^{2}{ }^{2}$ ricardas.krikstolaitis@vdu.lt
}

Received 18 May 2020; accepted 15 August 2020; published 30 December 2020

\begin{abstract}
The paper is directed to an important yet controversial phenomena of public perception of nuclear energy in Lithuania. It discusses the conceptualization of nuclear energy public perception in relation to psychometric paradigm and its specified key elements of public security feelings. The empirical research is based on representative public poll carried out in 2017. Based on the discoveries of previous research when identifying the interdependence of public perception and support towards concrete political parties, four clusters were formed to test conceptual notions (importance of personal trust in energy industry and personal knowledge) and then relate it with the political preferences of each cluster. The results indicate the distribution of both nuclear energy as well as concrete energy projects public perception in relation to political preferences and peculiarities of security feeling among each cluster.
\end{abstract}

Keywords: nuclear energy; public perception; political priorities; change; cluster analysis; Lithuania

Reference to this paper should be made as follows: Genys, D., Krikštolaitis, R. 2020. Clusterization of public perception of nuclear energy in relation to changing political priorities. Insights into Regional Development, 2(4), 750-764. http://doi.org/10.9770/IRD.2020.2.4(2)

JEL Classifications: Z18, Z19, C12, C19

Additional disciplines political sciences; sociology

\section{Introduction}

Paradoxically enough, the construction of Ostrovets Nuclear Power Plant (NPP) in Belarus brings nuclear energy back as one of the hottest topics in Lithuanian public discourse. It is internationally known that Lithuania puts a lot of energy in trying to oppose Ostrovets NPP. There is plenty of analytical attempts (Juozaitis 2016; Molis 2011) to outline the ongoing happenings as well as to prognose possible future developments. Even though Lithuanian considerations are very specific with respect to concrete ONPP project and geopolitical tension it creates, on the other hand it somehow address broader discussion regarding the future of nuclear energy in general (Adamantiades and Kessides 2009; Kessides 2012). Alas, there is almost no contribution on societal opinion, although it is one of the main factors, which will likely grow in future, especially when the NPP will be launched 


\section{INSIGHTS INTO REGIONAL DEVELOPMENT}

ISSN 2669-0195 (online) http://jssidoi.org/jesi/ 2020 Volume 2 Number 4 (December)

http://doi.org/10.9770/IRD.2020.2.4(2)

and its energy will be provided to the market. Having in mind rich Lithuanian history of both the nuclear energy ambitions and the dynamics of public perception it opens new angles for further analysis of the topic.

Lithuania might be one of the most interesting cases for those analysing public perception of nuclear energy due to its interdependence with people's support to concrete political parties. The studies indicated that public perception of energy security in Lithuania is based on what political actors people support and the energy policy of which political powers they support. In other words, priority to political powers also leads to the construction of their perception of energy security. Therefore, in those cases where political elements of certain powers coincide, the perception coincides as well. Different social groups value the energy policy of Lithuania according to their prioritization of the political power (Leonavičius, Genys, Krikštolaitis 2018). This is not very typical, but it explains why and how public support to nuclear energy eventually decreased and it became irrelevant in overall public assessment of energy security.

The goal of the paper is to analyse and cluster the division of public attitude towards nuclear energy based on societal trust in energy industry and personal knowledge (about energy security) and relate it with the division of the support to political parties. In doing so paper adapts psychometric paradigm. For sociologist, the value of $P$. Slovic theory lies in accepting that the public's perception of risk is influenced by social, cultural, economic and political factors. The paper contributes to the broader discussion on the worldwide dynamics of nuclear perception, especially addressing the issues of what determines public attitude to nuclear energy (Goodfellow et al. 2014; Poortinga, Pidgeon and Lorenzoni 2006; Jewell 2011) and whether it is related with political participation (Engels et al. 2013; Wagner, Grobelski and Harembski 2016) and what makes people safe (Siegrist, Sütterlin and Keller 2014; Bird et al. 2014; Tvaronavičienė, Nesterova and Kováčik 2017) as well as energy security dynamics in contemporary Europe (Balitskiy, Bilan and Strielkowski 2014; Abrhám et al. 2018; Dźwigoł et al. 2019). The research is focused upon inner processes (dynamics of public discourse, change of political priorities etc.) rather than external (like accidents, foreign experience, etc.). In Lithuania, the relevance of Slovic's theory corresponds to its identified contradiction in risk assessment between expert and lay people, and how it is rationalized and how it can impact or even overcome each other, for example, when extensive communication campaigns are embodied to change institutional energy policy (like in shale gas and nuclear energy cases).

The paper is based on empirical research (public poll) carried out in 2017. Representative survey was conducted by public opinion research company "Vilmorus" in March 2017. Number of respondents: $\mathrm{N}=1002$; interviewed 18 years old and older residents of Lithuania. In both cases the method of survey: questioning respondents at home using pre-made questionnaires. Method of selection: multi-stage, probabilistic sampling. Selection of respondents was prepared so that each resident of Lithuania should have an equal chance of being questioned. The results reflect the opinion of the entire population of Lithuania and distribution by age, sex, place of residence, education, purchasing power. Error of survey results - 3\% (probability - no less than 97\%).

\section{Conceptualizing Public Perception of Nuclear Energy}

The "psychometric paradigm" developed by Slovic, Fischhoff, and Lichtenstein was a landmark in research about public attitudes toward risks. This paradigm produced a "cognitive map" of hazards, and the assumption seemed to be that the characteristics identified were inherent attributes of risk (Marris et al. 1997).

Slovic masterfully summarizes the key qualitative characteristics that result in judgments that a certain activity is risky or not. People tend to be intolerant of risks that they perceive as being uncontrollable, having catastrophic potential, having fatal consequences, or bearing an inequitable distribution of risks and benefits (Gorman 2013). Slovic notes that nuclear power score high on all of these characteristics. Also unbearable in the public view are risks that are unknown, new, and delayed in their manifestation of harm (Slovic 1996).

Paul Slovic (1987) in his classic article summarized various social and cultural factors that lead to inconsistent evaluations of risk in the general public. According to P. Slovic perception of the risk - is intuitive assessment of dangers deriving from technology (1987). He emphasizes the essential way in which experts' and lay people's 


\section{INSIGHTS INTO REGIONAL DEVELOPMENT}

ISSN 2669-0195 (online) http://jssidoi.org/jesi/

2020 Volume 2 Number 4 (December)

http://doi.org/10.9770/IRD.2020.2.4(2)

views of risk differ. Experts judge risk in terms of quantitative assessments of morbidity and mortality. Yet most people's perception of risk is far more complex, involving numerous psychological and cognitive processes.

The key issues related to public views on nuclear power include trust in nuclear industry, understanding of nuclear technology and confidence in "expert" views on risk issues such as reactor safety and the long-term solutions for the storage and/or disposal of radioactive waste (Demski, Poortinga and Pidgeon 2014). The nuclear energy usually is presented as a vivid example of such a schism between technological expertise and assurance of NPP's safety and public scepticism and mistrust in such guarantees (Pidgeon, Lorenzoni and Poortinga 2008; Novikau 2016).

Slovic aptly noted, that "the public perception has evoked harsh reactions from experts". And provided some examples of the reaction ("the irrational fear of nuclear plants is based on a mistaken assessment of the risks"; "the public has been driven insane over fear of radiation. I use the word "insane" purposefully since one of its definition is loss of contact with reality"). However, his research on public risk perception provides different picture, "demonstrating that people's deep anxieties are linked to the reality extensive unfavorable media coverage and to strong association between nuclear power and the proliferation and use of nuclear weapon" (Slovic 1987). Further studies (Pidgeon, Kasperson and Slovic 2003; Goodfellow et al. 2014) have confirmed the notion and even stronger related the dependence of public attitudes on contextual portrayal of nuclear energy. The public gains most of its information on energy and nuclear power from the media, but does not trust it. Scientists and environmental protection or consumer organizations are the most trusted groups. National governments are, in general, even less trusted on these issues than the media (NEA and OECD 2010).

According to Slovic "lay people sometimes lack certain information about hazards. However, their basic conceptualization of risk is much richer than that of the experts and reflects legitimate concerns that are typically omitted from expert risk assessments. As a result, risk communication and risk management efforts are destined to fail unless they are structured as two-way process. Each side, expert and public, has something valid to contribute" (Slovic 1987). Having in mind the differences in expert and public risk perception it is important that society would be well informed and have clear information about the advantages and main dangers of NPP (and nuclear energy in general) in order to avoid emotionally based assessment of the latter.

Therefore, the safety experts of nuclear power should be attentive to and sensitive about the public's broad conception of risk (Gorman 2013). Slovic argues that risk management is a two-way street: just as the public should take experts' assessments of risk into account, so should experts respect the various factors, from cultural to emotional, that result in the public's perception of risk (Slovic 1987).

Regrettably, in some cases the defenders of nuclear energy (or other dangerous products in general) use Slovic's thesis to dismiss lay people"s perceptions of risk: by hiring "experts" who minimize or disparaged the affected individuals' "over-reaction," and "unscientific" assessment of potential harm, and provide contradictory arguments full of „statistics“, „,strategic interest“ and other ,important“ reasoning, allowing the "experts” to convince decision-makers and opinion leaders that the lay people's perception of risk is wrong.

\section{Subjective dimension of risk construction}

Throughout its history nuclear energy has been controversial and susceptible to instinctive public reaction. There are large sections of the public with no firm views for or against nuclear energy in many countries. The data clearly shows that countries already include nuclear power in the energy mix have publics that are more knowledgeable on the issues and are more supportive. Which come first is not clear (NEA and OECD 2010). A strong emphasis on knowledge production institutes (like science and media) was put by risk specialist U. Beck, who says that a vast knowledge on certain events and its possible danger and negative consequences transforms it into risk (Beck 2005). Risk become "visible" only when defined. In this sense, the nature of the risk is related not 


\section{INSIGHTS INTO REGIONAL DEVELOPMENT}

ISSN 2669-0195 (online) http://jssidoi.org/jesi/

2020 Volume 2 Number 4 (December)

http://doi.org/10.9770/IRD.2020.2.4(2)

only to objective events or phenomena, but to the constructive formulation of those events. The overall social, political, economic and even cultural climate, so called epistemological context, are important for the final definition of risk, when definition of risk depend on certain interpretation of contextual aspects (Cottle 1998). From this point of view, the risk is not necessarily a reflection of the reality but a socially constructed perception (Scott 2005). For example, compared to other technologies, nuclear risks always seem "bigger" and the benefits seem "less" due to viable stereotypes that nuclear energy is "unsafe", "uncontrolled", "deadly", "catastrophic". The perception of nuclear risk forms gradually, which makes them historic and rather inert. Authorities responsible for risk control tend to have long-term scepticism and mistrust in society.

Paraphrasing Ulrich Beck (2006), the subjective dimension of risk construction is related to different power groups, thus the definition of energy security is the object of competition among numerous energy security policy makers who not only pursue different goals, but also have different capabilities to interpret energy risks and dangers in their own way.

It is worth remembering that nuclear energy in Lithuania was the one of the main aspects to which public's and decision makers (including differences among them) attitudes' contradicted the most (Leonavičius, Genys 2017). Political decision-makers and society have somewhat different perceptions of energy security. The first identifies energy security with the possibility of free choice of energy suppliers, supply routes and energy resources, and with favourable energy prices. Meanwhile the second ( $3 / 4$ of society) prefer low energy prices rather than energy independency. In other words, energy independence and energy affordability for Lithuanians are not equal priorities when the latter is much more important.

Why does Lithuanian society support energy policy, but is opposed to its implementation measures? On the one hand, the opposition to energy infrastructure projects is related with problematic material situation of Lithuanian society, on the other hand, with the actions of the ruling elite.

- For poorly informed respondents, the goals of abstract and strongly ideological, for example, the so-called energy independence, energy security policy, are quite difficult to relate directly to their well-being, and energy infrastructure projects immediately provoke interest in investment and their potential taxes. The data show that the lower the respondent's income, the more it would contradict additional investments, which could increase the prices of energy resources, but even respondents with relatively high income support only slightly more than support investments in strategic energy projects.

- Trust in strategic energy projects is reduced not only by the fear of increased taxes, but also by distrust of the ruling elite. The collected data (Leonavičius and Genys 2017) reveal that respondents negatively assess the competence of both politicians and civil servants. The vast majority of respondents also do not think they represent the public interest. The lack of quality information, too prolonged politicians' debate and scandals due to corruption undermine public confidence in the success of strategic energy projects. Particularly damaging is the frequent change in the position of politicians, when a political party supports a project before one election, and is opposed or offered alternative offers by others.

It is not surprising that political parties have different approaches to energy policy. Right-wing political parties in the period of 2014-2017 were focusing on fossil fuels, meanwhile left-wing parties, especially peasants and Greens, campaigned for renewables and heavily criticized the possibility of shale gas extraction and nuclear power. Surveys have shown that the latter parties have been able to form critical public opinion on both the construction of the nuclear power plant and the extraction of shale gas, in the form of potential risks. Lithuanian energy policy documents focused more on fossil energy sources, and public opinion was that renewable energy was more important. Studies have shown that public discourse over the 2014-2017 period was particularly unfavourable for energy policy in relation to fossil energy sources and nuclear energy, as nearly half of the Lithuanian population rated politicians $(47.1 \%)$ and officials $(47.9 \%)$ poorly and very badly) opportunities for 


\section{INSIGHTS INTO REGIONAL DEVELOPMENT}

ISSN 2669-0195 (online) http://jssidoi.org/jesi/

2020 Volume 2 Number 4 (December)

http://doi.org/10.9770/IRD.2020.2.4(2)

efficient and competent solutions to energy sector problems (Leonavičius, Genys 2017). Having such unfavourable public discourse for the implementation of energy policy, the right wing parties could hardly convince the people of Lithuania of the usefulness of nuclear energy and shale gas.

Bearing in mind that public attitudes towards energy security depend on the political parties they support, it is worth analysing the implications of the political process for public opinion, such as the political fights among political parties (deconstruction of the ruling energy policy and continuous presentation of nuclear energy as a conductor of new problems rather than a solution) - how does it affects public attitude to nuclear energy and their security feeling?

\section{Clustering the perception of nuclear energy}

To summarize the most important factors that determine public perception of nuclear energy, on the one hand are awareness of the problem (individual understanding and knowledge on nuclear energy) and nuances of media coverage (variety of information sources and its evaluation), and finally, trust in nuclear industry (trust in science and in institution in charge of taking care of the nuclear energy risk).

Therefore, in the empirical part of the paper we will test two hypotheses. In the first case, we expect that people, who are better aware of the issue, are more critical to media performance, have diverse information sources and more trust in nuclear industry will be more positive to nuclear energy and will support the development of this kind of energy (Hypothesis 1).

In the second case, we expect that people, who less aware of the issue, are less critical to media performance, have singular information source and less trust in nuclear industry will be less positive to nuclear energy and will not support the development of this kind of energy (Hypothesis 2).

Both hypotheses were based on two theoretical notions. The first regards what has been called nuclear industry. According to literature (Slovic, Fischhoff and Lichtenstein 1986; Kasperson et al. 1988) the first hypothesis was formulated in following way: the more people trust in nuclear industry the less they worry about nuclear risks and they feel calmer and more support this kind of energy. And vice versa, the less trust, the more worry they fell about nuclear risks and feel anxious and less support this kind of energy.

For quite a long time Lithuania was nuclear energy producer, but in 2009 Ignalina NPP was decommissioned and we are not so called nuclear energy producer country any longer. Therefore, we had to modify the term nuclear industry and make it broader. We use energy industry analogy in this paper instead, which to our view performs the same function.

As we operationalize the energy industry we see it as it consists of key actors who form politics (government, parliament), provide expertise and run research (scientists), operate particular projects (municipalities), gain profit (private companies), advocate nuclear idea globally (international energy organizations), and even opponents (NGOs), finally, are in charge so to speak - controls nuclear industry (energy ministry). The operationalization of energy industry encompasses the list of 8 key actors who performs vivid role in energy industry (see Table 1). To get evaluation from respondents we formulated similar question - "Do You Trust the Influence of these Institutions and Organizations on Lithuanian Energy Policy?" - each time adding different actor. We believe such formulation describes the role of every actor in best way and express respondents' approval or disapproval.

The second notion is related to personal knowledge assessment and evaluation of media performance. According to literature (Slovic 1987; Sjöberg, Moen and Rundmo 2004; Poortinga, Aoyagi and Pidgeon 2013) the second hypothesis was formulated in following way: the more diverse information sources people have, the more critical they evaluates the information they get and the better they feel informed and are aware about the energy issue, the 


\section{INSIGHTS INTO REGIONAL DEVELOPMENT}

ISSN 2669-0195 (online) http://jssidoi.org/jesi/ 2020 Volume 2 Number 4 (December) http://doi.org/10.9770/IRD.2020.2.4(2)

less they worry about nuclear risks and they feel calmer and more support this kind of energy. And vice versa, the less diverse information sources people have, the less critical they evaluates the information they get and the worse they feel informed and are unaware about the energy issue, the more they worry about nuclear risks and feel anxious and less support this kind of energy. Media coverage plays huge role in shaping society's view towards nuclear energy. Having in mind media's hunger for scandalous stories nuclear energy and especially risk or even catastrophes frequently become "best-selling" stories. To escape the dependency on populist stories it is important to have diverse sources of information and critical attitude to media performance and their personal knowledge assessment. The operationalization of this notion encompass the list of 7 aspects regarding both the variety (special seminars, meetings, family, friends, colleagues, neighbours, news e-portals, paper, Radio, TV) and frequency of respondents information sources, critical attitude towards media (trust in media) and selfevaluation awareness on energy issue (awareness on energy security issues, knowledge of the advantages and disadvantages of nuclear energy). To get evaluation from respondents we formulated similar question - "How often do you get information about the energy policy from the following sources?" - each time adding different source and provided statements (see Table 1).

\section{Testing hypothesis and formation of the clusters}

The two step cluster analysis was performed in trying to track the distribution of the hypothesis among the public. The cluster analysis revealed four clusters which reflect four types of interrelation between two theoretical notions (trust in energy industry and personal knowledge assessment and evaluation of media performance) on which the hypotheses were based on (see Table 1).

Table 1. Final Cluster Centers.

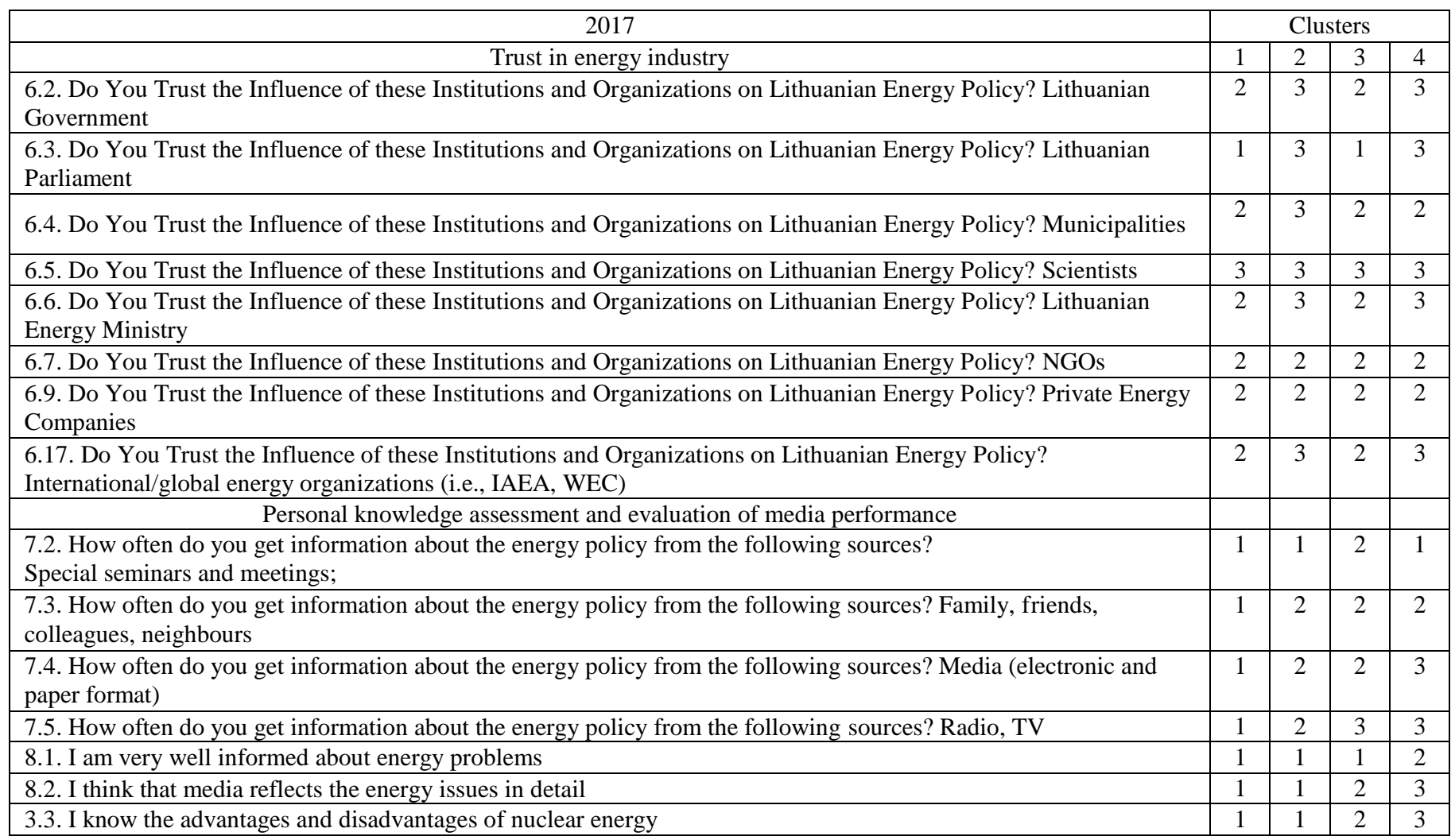


INSIGHTS INTO REGIONAL DEVELOPMENT

ISSN 2669-0195 (online) http://jssidoi.org/jesi/ 2020 Volume 2 Number 4 (December) http://doi.org/10.9770/IRD.2020.2.4(2)

To identify the common characteristics specific to each cluster, the hypothesis of homogeneity was tested in order to ascertain whether there are differences among clusters and whether these differences are statistically significant (see Table 2). The analysis show it has no statistically significant difference at 0.05 level between clusters members taking into account different age group (Pearson Chi-Square=18.740, $\mathrm{p}=0.226$ ), occupation (Pearson Chi-Square $=22.169, \mathrm{p}=0.225$ ) and education (Pearson Chi-Square $=26.578, \mathrm{p}=0.185$ ).

But the situation is different with other two socio-demographic characteristics: income and living areas. In both cases the homogeneity hypothesis is rejected, and the members of the cluster are distributed differently depending on the relevant characteristics. The analysis confirmed the existence of statistically significant differences among cluster regarding income (Pearson Chi-Square $=71.284, \mathrm{p}=0.000$ ) and living area (Pearson Chi-Square $=32.872$, $\mathrm{p}=0.000$ ).

Table 2. The main features of the clusters.

\begin{tabular}{|c|c|c|c|}
\hline $\begin{array}{c}1^{\text {st }} \text { cluster }- \text { Doubtful/uncertain, } \\
\text { unaware }\end{array}$ & $\begin{array}{l}2^{\text {nd }} \text { cluster }- \text { Confident/certain, } \\
\text { poorly informed, unaware }\end{array}$ & $\begin{array}{c}3^{\text {rd }} \text { cluster - Doubtful/uncertain, } \\
\text { poorly informed, aware }\end{array}$ & $\begin{array}{c}4^{\text {th }} \text { cluster }- \\
\text { Certain, aware }\end{array}$ \\
\hline
\end{tabular}

Speaking about similarities among clusters two tendencies can be distinguished. First, all clusters maintained huge support for scientists. Second, uncertainty or unaware regarding the role of both NGO and international organization are also common among clusters. Even though there were some changes in assessing personal knowledge and media performance within some of the clusters there are no any similarities among clusters. 
INSIGHTS INTO REGIONAL DEVELOPMENT

ISSN 2669-0195 (online) http://jssidoi.org/jesi/

2020 Volume 2 Number 4 (December)

http://doi.org/10.9770/IRD.2020.2.4(2)

Even though there is no statistically significant difference regarding employment it is interesting to note that the $1^{\text {st }}$ cluster has the biggest unemployed population (10.9\%) and those who have Other activities $(6.3 \%)$ as well as State enterprise employees (17.6\%). It also has the smallest Private company employee's population (21.3\%). The $2^{\text {nd }}$ on the contrary - has the smallest populations of State enterprise employees (11\%), Private business owners $(5.9 \%)$ and at the same time Unemployed (4.6\%), but has the biggest Retired population $(38.8 \%)$. The $3^{\text {rd }}$ cluster has the biggest both Private business owners $(8.4 \%)$ and Private company employees $(30.9 \%)$ populations. The $4^{\text {th }}$ cluster has no particular peculiarities (maybe with exception of quite large State enterprise employees' population $-17.3 \%$ ) and are close to total average of every category.

Finally, there is no statistically significant difference regarding education, but the tendencies, however, are quite notable and interesting. The $1^{\text {st }}$ cluster has biggest population with Secondary education $(26 \%)$ and quite large populations with Vocational (18.4\%) and Higher education (22.9\%), and the smallest Further education (18.8\%). The $2^{\text {nd }}$ cluster has biggest population with Primary $(12.2 \%)$ and Vocational education $(20.3 \%)$ and quite large Secondary Education $(23 \%)$, and the smallest Higher education $(17.6 \%)$. The $3^{\text {rd }}$ cluster doesn't have significant peculiarities and with the exception of Primary education is very similar to total average by all categories. The $4^{\text {th }}$ cluster has the biggest population with Higher education $(32 \%)$ and the smallest populations with Secondary education $(20.9 \%)$ and Vocational training (11.9\%).

\section{Clusters correlation with political parties}

In a brief overview of the priorities of the ruling parties' energy policy, we saw that until 2012, no opposition force questioned the importance of nuclear energy (construction of new NPP) for Lithuania's energy security, but had different opinion on specific measures - how to implement it. Until finally, the idea of a public referendum was raised, allowing the public to express their will for the future of nuclear energy. Assuming that the change in public opinion (from strong support to relative confusion) is related to the inconsistency of the nuclear energy discourse and the new contextual meanings surrounded new NPP (from a project which solves problems to a project which creates problems;), it is worth analysing the interrelations between clusters and their support for political parties, as well as some of the strategic directions of energy policy (see Table 3).

Table 3. Political preferences of clusters (distribution of support to political parties).

\begin{tabular}{|c|c|c|c|}
\hline $\begin{array}{c}1^{\text {st }} \text { cluster }- \text { Doubtful/uncertain, } \\
\text { unaware }\end{array}$ & $\begin{array}{c}2^{\text {nd }} \text { cluster - Confident/certain, } \\
\text { poorly informed, unaware }\end{array}$ & $\begin{array}{c}3^{\text {rd }} \text { cluster - Doubtful/uncertain, } \\
\text { poorly informed, aware }\end{array}$ & $\begin{array}{c}4^{\text {th }} \text { cluster }- \\
\text { Certain, aware }\end{array}$ \\
\hline \multicolumn{4}{|c|}{ Distribution of clusters' support to political parties* } \\
\hline \multicolumn{4}{|c|}{ Statistically significant differences of clusters opinion about support to political parties $(\mathrm{p}=0.000$, for all cases) } \\
\hline
\end{tabular}


INSIGHTS INTO REGIONAL DEVELOPMENT

ISSN 2669-0195 (online) http://jssidoi.org/jesi/

2020 Volume 2 Number 4 (December)

http://doi.org/10.9770/IRD.2020.2.4(2)

\begin{tabular}{|c|c|c|c|}
\hline $\begin{array}{l}\text { of energy independence despite } \\
\text { larger financial investments } \\
\text { needed for this }(30 \%)\end{array}$ & $\begin{array}{l}\text { care of energy independence } \\
\text { despite larger financial } \\
\text { investments needed for this } \\
(41 \%) \text {. }\end{array}$ & $\begin{array}{l}\text { of low cost energy resources } \\
\text { rather than energy independence } \\
(45.1 \%) \text {. }\end{array}$ & $\begin{array}{l}\text { care of energy independence } \\
\text { despite larger financial } \\
\text { investments needed for this } \\
(31.6 \%) \text {. }\end{array}$ \\
\hline \multicolumn{4}{|c|}{ A wellfunctioning democracy is essential for energy security } \\
\hline $\begin{array}{l}71 \% \text { absolutely agree/agree; } \\
10.7 \% \text { absolutely } \\
\text { disagree/disagree; } 17.5 \% \text { do not } \\
\text { know/did not respond. }\end{array}$ & $\begin{array}{l}83.8 \% \text { absolutely agree/agree; } \\
5.5 \% \text { absolutely } \\
\text { disagree/disagree; } 10.8 \% \text { do not } \\
\text { know/did not respond. }\end{array}$ & $\begin{array}{l}90.1 \% \text { absolutely agree/agree; } \\
3.6 \% \text { absolutely } \\
\text { disagree/disagree; } 6.3 \% \text { do not } \\
\text { know/did not respond. }\end{array}$ & $\begin{array}{l}69.4 \% \text { absolutely } \\
\text { agree/agree; } 6.2 \% \text { absolutely } \\
\text { disagree/disagree; } 24.3 \% \text { do } \\
\text { not know/did not respond. }\end{array}$ \\
\hline \multicolumn{4}{|c|}{ Statistically significant differences of clusters opinion about democracy $(\mathrm{p}=0.000)$} \\
\hline \multicolumn{4}{|c|}{ The problem of energy security in Lithuania is addressed taking into consideration the interests of all social groups } \\
\hline $\begin{array}{l}68.1 \% \text { - absolutely } \\
\text { disagree/disagree; } 16.1 \% \text { - } \\
\text { absolutely agree/agree; } \\
15.7 \% \text { - do not know. }\end{array}$ & $\begin{array}{l}58.1 \% \text { - absolutely } \\
\text { disagree/disagree; } 25.2 \% \text { - } \\
\text { absolutely agree/agree; } \\
16.7 \% \text { - do not know. }\end{array}$ & $\begin{array}{l}49.4 \% \text { - absolutely } \\
\text { disagree/disagree; } 37.6 \% \text { - } \\
\text { absolutely agree/agree; } \\
13 \% \text { - do not know. }\end{array}$ & $\begin{array}{l}58.2 \% \text { - absolutely } \\
\text { disagree/disagree; } 17.8 \% \text { - } \\
\text { absolutely agree/agree; } \\
24 \% \text { - do not know. }\end{array}$ \\
\hline \multicolumn{4}{|c|}{ I positively value energy security politics of Lithuanian Government } \\
\hline \multicolumn{4}{|c|}{ Statistically significant differences of clusters opinion about LG politics $(\mathrm{p}=0.000)$} \\
\hline \multicolumn{4}{|c|}{ Russia seeks to maintain Lithuania in its sphere of influence } \\
\hline $\begin{array}{l}49.8 \% \text { - absolutely } \\
\text { disagree/disagree }\end{array}$ & $69.8 \%$ - absolutely agree/agree & $71.2 \%$ - absolutely agree/agree & $\begin{array}{l}46.1 \% \text { absolutely agree/agree } \\
\text { (but } 34.2 \% \text { don't know) }\end{array}$ \\
\hline
\end{tabular}

Further differences among clusters emerged after cross-tabulation analysis between clusters and various statements. When assessing the distribution of political priorities, the second and third clusters are similar but strongly different from the first and the fourth. The first cluster is sceptical and undecided, somewhat supportive of government, but pragmatic and anti-establishment - agrees with the importance of democracy for energy security, but does not agree the interests of all social groups are taken into consideration when addressing the problem of energy security, sceptical of government politics and do not believe that Russia is trying to keep Lithuania in its area of influence.

The second and third are strongly political and support similar parties (a slight difference - the second is somewhat less oppose to the Conservatives, and the third is somewhat less oppose to the Socialdemocrats). If we agree with the assumption that their perception of energy security is determined by the political parties they support, it is not surprising that there is no conceptual difference between the second and the third clusters, as there are no fundamental differences between the parties (but there are some differences regarding implementing measures of energy security). It should be remembered that the second is somewhat less informed, but is more confident in the industry and the third is less confident but slightly more informed. The third is the most supportive for the government, and is in most favour of energy independence (somewhat reflection of political elite attitudes frequently reflected in the media).

The fourth cluster (similar to the first one) is the most sceptical regarding all political parties, but trusts in industry and is well informed. The least (in comparison to others) believes that democracy is necessary for energy security and is the most undecided - whether the energy security problem is addressed taking into consideration the interests of all social groups. Opposes to the Governmental politics the most and is most doubtful regarding Russia's interests in Lithuania. 
INSIGHTS INTO REGIONAL DEVELOPMENT

ISSN 2669-0195 (online) http://jssidoi.org/jesi/

2020 Volume 2 Number 4 (December)

http://doi.org/10.9770/IRD.2020.2.4(2)

\section{Attitude division among clusters}

For the identification of the most important energy security aspects, respondents were provided the vast variety of different energy security aspects for the evaluation of each them according to personal opinion. The energy security aspects were formed in line with Lithuanian strategic interests and covered different angles of energy security: diversification (of energy suppliers as well as resources), reliability (of supply and infrastructure), independence (from foreign states (mainly Russia) as well as monopolistic practices), ability to take advantage of international political relations (e.g., EU, NATO) to defend Lithuanian interests, synchronization of electricity grid with continental European zone, to mitigate the development of nuclear energy in neighbouring countries (Ostrovets (Belarus) and Kaliningrad (Russia)), lastly - evaluation of strategic projects to be implemented in upcoming future (renewable energy, shale gas, nuclear energy) (see Table 4).

Table 4. Attitude to energy security differences among clusters.

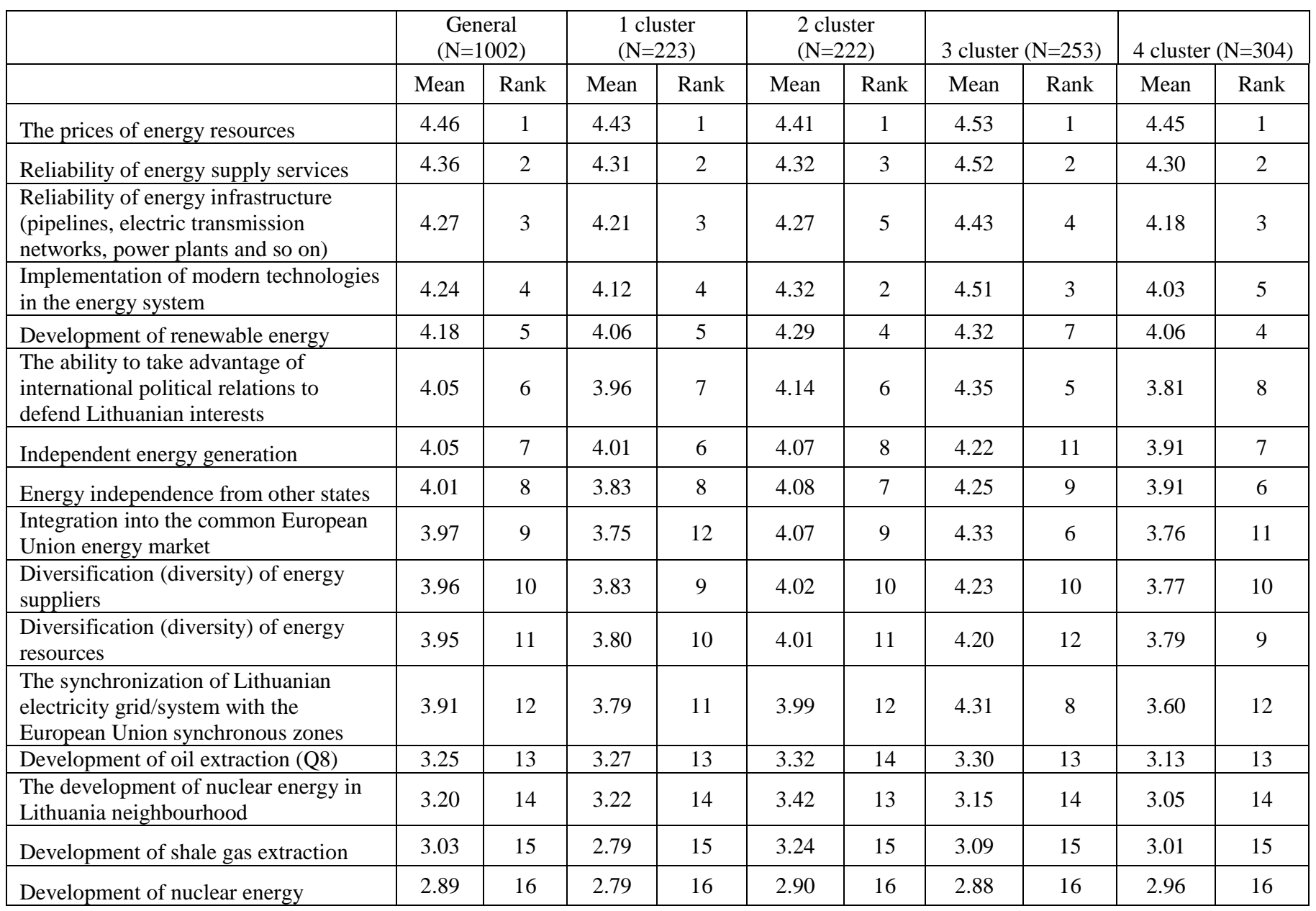

The analysis showed that two the most important aspects are The prices of energy resources and Reliability of energy supply services among clusters (with exception of the second cluster when the latter aspects moves into third place). The four less important (in reversed order) The development of nuclear energy, The development of shale gas, The development of nuclear energy in Lithuania neighbourhood (Ostrovets in Belarus and the Baltic Kaliningrad nuclear power plant) (which in case of the second cluster switches places with Q8), The development of oil extraction (Q8). Thus, we see the strong domination of the most and the least important aspects on the one 
INSIGHTS INTO REGIONAL DEVELOPMENT

ISSN 2669-0195 (online) http://jssidoi.org/jesi/ 2020 Volume 2 Number 4 (December) http://doi.org/10.9770/IRD.2020.2.4(2)

hand, and quite diverse attitude distribution among clusters regarding other aspects of energy security in Lithuania on the other. Therefore, data revealed consistent public support to general direction of energy security (independent and cheap energy) which all political parties agree on. However, the attitude to its implementation measures are quite mixed, as various political parties articulated it in their own way.

Finally, the further analysis of the attitude to various aspects related to nuclear energy revealed certain tendencies among clusters (see Table 5).

Table 5. Perception variations among 4 clusters. "Is the development of nuclear energy important for Lithuanian energy security?"

\begin{tabular}{|l|c|c|c|c|c|}
\hline \multirow{2}{*}{} & \multicolumn{4}{|c|}{ Clusters } & \multirow{2}{*}{ Total } \\
\cline { 2 - 5 } & 1 & 2 & 3 & 4 & $42.9 \%$ \\
\hline Totally disagree/ disagree & $44.8 \%$ & $44.1 \%$ & $39.1 \%$ & $44.7 \%$ & $20.2 \%$ \\
\hline Don't know/undecided & $19.3 \%$ & $17.6 \%$ & $25.0 \%$ & $17.4 \%$ & $36.9 \%$ \\
\hline Agree/totally agree & $35.9 \%$ & $38.3 \%$ & $35.9 \%$ & $37.9 \%$ & $100.0 \%$ \\
\hline Total & $100.0 \%$ & $100.0 \%$ & $100.0 \%$ & $100.0 \%$ & \\
\hline
\end{tabular}

There are almost no differences in attitude regarding nuclear energy importance for Lithuanian energy security among clusters (Table 5), unless higher undecidedness in the third cluster. But there are few notable differences regarding evaluation of the knowledge on the advantages and disadvantages of nuclear energy (Table 6).

Table 6. Perception variations among 4 clusters. "I know the advantages and disadvantages of nuclear energy"

\begin{tabular}{|l|c|c|c|c|c|}
\hline \multirow{2}{*}{} & \multicolumn{4}{|c|}{ Clusters } & \multirow{2}{*}{ Total } \\
\cline { 2 - 5 } & 1 & 2 & 3 & 4 & $47.9 \%$ \\
\hline Totally disagree/ disagree & $72.2 \%$ & $74.8 \%$ & $40.1 \%$ & $12.3 \%$ & $11.2 \%$ \\
\hline Don't know/undecided & $5.8 \%$ & $6.7 \%$ & $20.8 \%$ & $8.3 \%$ & $40.9 \%$ \\
\hline Agree/totally agree & $22.0 \%$ & $18.5 \%$ & $39.1 \%$ & $79.4 \%$ & $100.0 \%$ \\
\hline Total & $100.0 \%$ & $100.0 \%$ & $100.0 \%$ & $100.0 \%$ & \\
\hline
\end{tabular}

The $1^{\text {st }}$ and the $2^{\text {nd }}$ clusters hugely disagree (accordingly $72.2 \%$ and $74.8 \%$ ) with the statement "I know the advantages and disadvantages of nuclear energy". Meanwhile the 4th cluster on the contrary - has the smallest population who disagree $(12.3 \%)$ and the largest who agree $(79.4 \%)$. The $3^{\text {rd }}$ cluster is divided into two similar groups who disagree $(40.1 \%)$ and agree $(39.1 \%)$. These differences cannot be explained by political priorities, nor clusters' trust in nuclear industry but is closely related with informativity. The largest groups who agree belongs to $4^{\text {th }}$ cluster which is well informed, and its members evaluate their knowledge positively. Even the $3^{\text {rd }}$ cluster, which is somewhat less informed demonstrated better results (comparing to first two clusters) See Table 7 below.

Table 7. Perception variations among 4 clusters. "Do you agree with the construction of Visaginas NPP?"

\begin{tabular}{|l|c|c|c|c|c|}
\hline \multirow{2}{*}{} & \multicolumn{3}{|c|}{ Clusters } & \multirow{2}{*}{ Total } \\
\cline { 2 - 5 } & 1 & 2 & 3 & 4 & $56.3 \%$ \\
\hline Totally disagree/ disagree & $62.3 \%$ & $57.2 \%$ & $49.7 \%$ & $58.1 \%$ & $24.0 \%$ \\
\hline Don't know/undecided & $21.6 \%$ & $26.1 \%$ & $30.2 \%$ & $17.0 \%$ & $19.7 \%$ \\
\hline Agree/totally agree & $16.1 \%$ & $16.7 \%$ & $20.1 \%$ & $24.9 \%$ & $100.0 \%$ \\
\hline Total & $100.0 \%$ & $100.0 \%$ & $100.0 \%$ & $100.0 \%$ & \\
\hline
\end{tabular}

As mentioned before Visaginas NPP (VNPP) were the object for many heated discussions and quite frequently the interpretations view inconsistent and even controversial. To clarify public attitude general questions regarding support or unsupported the construction of VNPP were left in the poll even though it is clear Lithuania won't come back to nuclear energy production. The division of attitude among clusters distributed differently than in case of importance of nuclear energy for energy security. If in previous case the $1^{\text {st }}$ cluster didn't distinguish by 


\section{INSIGHTS INTO REGIONAL DEVELOPMENT}

ISSN 2669-0195 (online) http://jssidoi.org/jesi/

2020 Volume 2 Number 4 (December)

http://doi.org/10.9770/IRD.2020.2.4(2)

significant peculiarities, in this case on the contrary, we see that it is the less supportive (16.1\%) and the most critical $(62.3 \%)$. The $2^{\text {nd }}$ similarly less supportive $(16.7 \%)$ but at the same time less critical $(57.2 \%)$. The $3^{\text {rd }}$ is the most indecisive $(30.2 \%)$ and also more supportive $(20.1 \%)$ and the less critical $(49.7 \%)$. The $4^{\text {th }}$ is the most supportive (24.9\%), the less indecisive (17\%) and yet quite critical (58.1\%).

The impact of both cluster's trust in energy industry and informativity interrelation and cluster's perception dependence on political parties' policy can be traced in this case. First of all, there is a tendency moving through clusters from $1^{\text {st }}$ (doubtful/uncertain, unaware) to $4^{\text {th }}$ (slightly doubtful/certain, informed, ware) in supporting the construction of VNPP. The $1^{\text {st }}$ cluster not only is doubtful/uncertain, unaware but also sceptical and less supporting governmental politics. The $4^{\text {th }}$ is also sceptical but trusts in industry and have enough knowledge to make autonomous decision. Secondable, the $3^{\text {rd }}$ cluster is a vivid illustration of consequences of nuclear energy battles among various political parties: this cluster is most political and most supportive for governmental policy and therefore has the largest indecisive group, the smallest who disagree, and some who agree. One could presume that features of the $3^{\text {rd }}$ cluster perception reflects the kaleidoscope of nuclear politics. Finally, the $2^{\text {nd }}$ cluster is less indecisive, but more opposing and less supportive. Even though from political preferences point of view this cluster is similar to previous, the differences come from its pragmatism (priority to price) and doubt that energy security problem is addressed taking into consideration the interests of all social groups. Having in mind the negative discourse regarding nuclear energy (that it might contribute to creation of new problems) there are notable differences in attitude even though it also strongly supports governmental policy.

To sum up, it seems that the society started to think more frequently that the development of nuclear energy is dangerous. It could be related not only to the criticism of VNPP in the media but also to the development of nuclear energy in Lithuanian neighbourhood.

\section{Conclusions}

Based on unique type of interrelation between two theoretical notions (trust in energy industry and personal knowledge assessment and evaluation of media performance) four clusters were formulated. Both - trust in energy industry as well as personal knowledge assessment and evaluation of media performance - have impact on perception of nuclear energy. As the analysis has shown each aspect have different consequences to public perception: the doubt or uncertainty towards energy industry results in indecisiveness and insecurity. Meanwhile lack of personal knowledge or dependence on solely information source and uncritical evaluation of media performance results in scepticism and anxiety.

The data analysis revealed consistent public support to general direction of energy security despite existing difference among clusters regarding political preferences. However, the attitude to concrete projects and implementation measures are quite mixed, as various political parties articulated it differently. There are almost no differences in attitude regarding nuclear energy importance for Lithuanian energy security among clusters (Table 5), but there are notable difference among clusters regarding both deeper understanding of advantages and disadvantages of nuclear energy and the construction of new VNPP, both of which depend on clusters' interrelation between trust in energy industry and awareness of the problem and political preferences.

The cluster analysis confirmed the relation between cluster's trust in energy industry and informativity interrelation as well as clusters' perception dependence on political parties'. There is a tendency moving through clusters from 1st (doubtful/uncertain, unaware, also sceptical and less supporting governmental politics) to 4th (slightly doubtful/certain, informed, aware, is also sceptical but trusts in industry and have enough knowledge to make autonomous decision) in supporting the construction of VNPP. Secondable, the 3rd cluster is a vivid illustration of consequences of nuclear energy battles among various political parties: this cluster is most political and most supportive for governmental policy and therefore has the largest indecisive group, the smallest who 


\section{INSIGHTS INTO REGIONAL DEVELOPMENT}

ISSN 2669-0195 (online) http://jssidoi.org/jesi/ 2020 Volume 2 Number 4 (December)

http://doi.org/10.9770/IRD.2020.2.4(2)

disagree, and some who agree. Meanwhile, the 2nd cluster is less indecisive, but more opposing and less supportive. Even though from political preferences point of view this cluster is like previous, the differences come from its pragmatism (priority to price) and doubt that energy security problem is addressed taking into consideration the interests of all social groups.

\section{References}

Abrhám, J., Britchenko, I., Jankovic, M., Garškaitė-Milvydienė, K. 2018. Energy security issues in contemporary Europe, Journal of Security and Sustainability Issues 7(3): 387-398. https://doi.org/10.9770/jssi.2018.7.3(1)

Adamantiades, A., Kessides, I. 2009. Nuclear power for sustainable development: current status and future prospects. Energy Policy 37: 5149-5166. https://doi.org/10.1016/i.enpol.2009.07.052.

Cottle, S. 1998. Ulrich Beck, 'Risk Society' and the Media. A Catastrophic View? European Journal of Communication 13(1): 5-32. https://doi.org/10.1177/0267323198013001001.

Balitskiy, S., Bilan, Y., Strielkowski, W. 2014. Energy security and economic growth in the European Union. Journal of Security and Sustainability Issues 4(2): 125-132. https://doi.org/10.9770/jssi.2014.4.2(2)

Beck, U. 2005. Risk Society Revisited: Theory, Politics and Research Programmes, in Adam, B., Beck, U., van Loon, J., (Eds.), The Risk Society and Beyond: Critical Issues for Social Theory. Sage Publications, London, 211-229.

Bird, D. K., Haynes, K., van den Honert, R., McAneney, J., Poortinga, W. 2014. Nuclear power in Australia: A comparative analysis of public opinion regarding climate change and the Fukushima disaster. Energy Policy 65: 644-653. https://doi.org/10.1016/j.enpol.2013.09.047.

Demski, C., Poortinga, W., Pidgeon, N. 2014. Exploring public perceptions of energy security risks in the UK. Energy Policy 66: 369-378. http://dx.doi.org/10.1016/j.enpol.2013.10.079.

Dźwigoł, H., Dźwigoł-Barosz, M., Zhyvko, Z., Miśkiewicz, R., Pushak, H. 2019. Evaluation of the energy security as a component of national security of the country. Journal of Security and Sustainability Issues 8(3): 307-317. http://doi.org/10.9770/jssi.2019.8.3(2)

Engels, A., Hüther, O., Schäfer, M., Held, H. 2013. Public climate-change skepticism, energy preferences and political participation. Globas Environmental Change 23(5): 1018-1027. https://doi.org/10.1016/j.gloenvcha.2013.05.008

Goodfellow, J. M., Dewick, P., Wortley, J., Azapagic, A. 2014. Public perceptions of design options of new nuclear plants in the UK. Process Safety and Environmental Protection 94: 72-88. https://doi.org/10.1016/j.psep.2014.12.008.

Gorman, S., 2013. How do we perceive risk?: Paul Slovic's landmark analysis. Retrieved from http://www.thepumphandle.org/2013/01/16/how-do-we-perceive-risk-paul-slovics-landmark-analysis-2/\#.XXcvfyj7TIU.

Jewell, J., 2011. Ready for nuclear energy? An assessment of capacities and motivations for launching new national nuclear power programs. Energy Policy 39(3): 1041-1055. https://doi.org/10.1016/j.enpol.2010.10.041.

Juozaitis, J., 2016. Lithuanian foreign policy vis-à-vis Belarusian nuclear power plant in Ostrovets. Lithuanian Foreign Policy Review 35(1): 41-66. https://doi.org/10.1515/lfpr-2016-0023.

Kasperson, R. E., Renn, O., Slovic, P., Brown, H. S., Emel, J., Goble, R., Kasperson, J. X., Ratick, S. 1988. The social amplification of risk: a conceptual framework. Risk Analysis 8(2): 177-187. https://doi.org/10.1111/j.1539-6924.1988.tb01168.x.

Kessides, N. I. 2012. The future of the nuclear industry reconsidered: risks, uncertainties, and continued promise. Energy Policy 48: 185208. http://dx.doi.org/0.1016/j.enpol.2012.05.008.

Leonavičius, V., Genys, D., Krikštolaitis, R. 2018. Public Perception of Energy Security in Lithuania: Between Material Interest and Energy Independence. The Journal of Baltic Studies 49(1): 157-175. https://doi.org/10.1080/01629778.2018.1446033

Leonavičius, V., Genys, D. 2017. Energy Security Sociology. Kaunas, Lithuania: Vytautas Magnus University, Kaunas. (in Lithuanian). 
INSIGHTS INTO REGIONAL DEVELOPMENT

ISSN 2669-0195 (online) http://jssidoi.org/jesi/ 2020 Volume 2 Number 4 (December)

http://doi.org/10.9770/IRD.2020.2.4(2)

Marris, C., Langford, I., Saunderson, T., O’Riordan, T. 1997. Exploring the "psychometric paradigm": comparisons between aggregate and individual analyses. Risk Analysis 17(3): 303-12. https://doi.org/10.1111/j.1539-6924.1997.tb00868.x.

Molis, A. 2011. Construction of Ostrovets Nuclear Power Plant: Whom to Trust and What to Expect? Energy Security Highlights. 74-76.

Novikau, A. 2016. Nuclear power debate and public opinion in Belarus: From Chernobyl to Ostrovets. Public Understanding of Science 5: 1-14. https://doi.org/10.1177/0963662516647242.

NEA, OECD. 2010. Public Attitudes to Nuclear Power. Report (NEA No. 6859). Retrieved from https://www.oecdnea.org/ndd/reports/2010/nea6859-public-attitudes.pdf

Pidgeon, N. F., Lorenzoni, I., Poortinga, W. 2008. Climate change or nuclear power - no thanks! A quantitative study of public perceptions and risk framing in Britain. Global Environmental Change 18(1): 69-85. https://doi.org/10.1016/j.gloenvcha.2007.09.005.

Pidgeon, N. F., Kasperson, R., Slovic, P. 2003. The Social Amplification of Risk. Cambridge: Cambridge University Press.

Poortinga, W., Aoyagi, M., Pidgeon, F. N. 2013. Public perceptions of climate change and energy futures before and after the Fukushima accident: A comparison between Britain and Japan. Energy Policy 62: 1204-1211. https://doi.org/10.1016/j.enpol.2013.08.015.

Poortinga, W., Pidgeon, N. F., Lorenzoni, I. 2006. Public perceptions of nuclear power, climate change and energy options in Britain: Summary findings of a survey conducted during October and November 2005. Tyndall Centre for Climate Change Research. School of Environmental Sciences. University of East Anglia. Retrieved from https://sp.ukdataservice.ac.uk/doc/5357/mrdoc/pdf/5357userguide.pdf

Siegrist, M., Sütterlin, B., Keller, C. 2014. Why have some people changed their attitudes toward nuclear power after the accident in Fukushima? Energy Polic. 69: 356-363. https://doi.org/10.1016/j.enpol.2014.02.026.

Scott, A., 2005. Risk Society or Angst Society? Two Views of Risk, Consciousness and Community, in Adam, B., Beck, U., van Loon, J., (Eds.), The Risk Society and Beyond: Critical Issues for Social Theory. London: Sage Publications, 33-46.

Sjöberg, L., Moen, B.-E., Rundmo, T., 2004. Explaining risk perception. An evaluation of the psychometric paradigm in risk perception research, Rotunde, Trondheim, Norway. Retrieved from http://www.svt.ntnu.no/psy/Torbjorn.Rundmo/Psychometric_paradigm.pdf

Slovic, P. 1996. Perception of risk from radiation. Radiation Protection Dosimetry 68:(3-4), 165-180. https://doi.org/10.1093/oxfordjournals.rpd.a031860

Slovic, P. 1987. Perception of Risk. Science 236(4799): 280-285. https://doi.org/10.1126/science.3563507.

Slovic, P., Fischhoff, B., Lichtenstein, S. 1986. The Psychometric Study of Risk Perception, in Covello, V.T., Menkes, J., Mumpower, J., (Eds.). Risk Evaluation and Management. Contemporary Issues in Risk Analysis, vol 1. Springer, Boston, MA.3-24. https://doi.org/10.1007/978-1-4613-2103-3_1.

Tvaronavičienė, M., Nesterova, K., Kováčik, V. 2017. Energy security and long-term energy efficiency: case of selected counties. Journal of Security and Sustainability Issues 7(2): 349-357. https://doi.org/10.9770/jssi.2017.7.2(14)

Wagner, A., Grobelski, T., Harembski, M. 2016. Is energy policy a public issue? Nuclear power in Poland and implications for energy transitions in Central and East Europe. Energy Research \& Social Science 13: 158-169. https://doi.org/10.1016/j.erss.2015.12.010. 
INSIGHTS INTO REGIONAL DEVELOPMENT

ISSN 2669-0195 (online) http://jssidoi.org/jesi/

2020 Volume 2 Number 4 (December)

http://doi.org/10.9770/IRD.2020.2.4(2)

Dainius GENYS, Doctor Sociology, researcher at Energy Security Research Center in Vytautas Magnus University, Kaunas, Lithuania. Research interests: energy security, public perception analysis, democratization studies.

Author ID: 54950162900

ORCID ID: https://orcid.org/0000-0003-1224-0127

Ričardas KRIKŠTOLAITIS, Doctor Mathematics, Professor of Department of Mathematics and Statistics at Vytautas Magnus University, Kaunas, Lithuania. Research interests: energy security, risk and reliability analysis, statistical data analysis.

ORCID ID: https://orcid.org/0000-0001-9556-4121

Copyright (C 2020 by author(s) and VsI Entrepreneurship and Sustainability Center

This work is licensed under the Creative Commons Attribution International License (CC BY).

http://creativecommons.org/licenses/by/4.0/

(c) (i) Open Access 